\title{
Effects of Lithium Addition on Daily Activity and Psychi- atric Symptoms in Schizophrenic Inpatients
}

\author{
Atsushi SOYA, Takeshi TERAO and Jun NAKAMURA \\ Department of Psychiatry, School of Medicine, University of Occupational and Environmental Health, \\ Japan. Yahatanishi-ku, Kitakyushu 807-8555, Japan
}

\begin{abstract}
Lithium addition to neuroleptic treatment brought about some improvement in 6 schizophrenic inpatients. In 3 of them, however, enhancement of daily activity did not parallel improvement in psychiatric symptoms. This suggests that lithium addition may enhance daily activity independently of psychiatric symptoms, and that lithium effects should also be assessed from the viewpoint of daily activity.
\end{abstract}

Key words:lithium, schizophrenia, daily activity, psychiatric symptoms.

(Received 4 July 2002, accepted 22 October 2002 )

\section{Introduction}

Lithium addition to neuroleptic treatment in schizophrenic patients may improve psychotic excitement, anxiety, depression and/or thought disorder $[1,2]$, although several studies found no response with lithium augmentation [3]. Particularly, lithium may improve anxiety and depression in schizophrenic patients without any hyperactivity or manic symptoms [1]. Given the results of the recent meta-analysis showing no evidence that atypical antipsychotics are more effective than conventional antipsychotics [4], lithium addition still deserves further study. On the other hand, to our knowledge, there has been no report suggesting that lithium affects the daily activity of schizophrenic patients.

In the present preliminary study, we report 6 cases of lithium-treated schizophrenia. Lithium effects on daily activity and psychiatric symptoms are investigated.

\section{Case Reports}

One of the authors (A.S.) treated all 6 patients consecutively, and assessed the changes in psychiatric symptoms and daily activity. Table 1 shows the patients' characteristics, lithium treatment, and the effects of such treatment on psychiatric symptoms and daily activity. Of the 6 patients, 5 were female and 1 was male. Psychiatric diagnoses based on DSM-IV criteria were schizophrenia in 5 patients and schizoaffective disorder in 1 patient. 
To measure daily activity, percentage in attendance at exercise and recreational activity in the psychiatric ward was calculated for 1 month just before lithium addition and for 1 month after it. Changes of psychiatric symptoms were assessed by A.S. without any established scale, as at that time he was blind to the results of daily activity. In accordance with the observation period, changes in psychiatric symptoms were also compared for 1 month just before lithium addition and for 1 month after it. The case histories are described below.

\section{Case 1}

Mr. M was a 22-year-old unmarried man. He had suffered from schizophrenia for six years. He had been on $9 \mathrm{mg}$ per day of haloperidol and $200 \mathrm{mg}$ per day of levomepromazine before

Table 1. Patients' characteristics, pharmacotherapy, changes in psychiatric symptoms and daily activity

\begin{tabular}{|c|c|c|c|c|c|c|c|c|}
\hline $\begin{array}{l}\text { Case } \\
\text { no. }\end{array}$ & $\begin{array}{l}\text { Age } \\
(\mathrm{yr})\end{array}$ & Gender & Diagnosis & \multicolumn{2}{|c|}{$\begin{array}{l}\text { Psychotropics just } \\
\text { before lithium addition } \\
\text { (mg) }\end{array}$} & $\begin{array}{l}\text { Serum lithium } \\
\text { level }(\mathrm{mEq} / \ell)\end{array}$ & $\begin{array}{l}\text { Improved } \\
\text { symptoms }\end{array}$ & $\begin{array}{l}\text { Daily } \\
\text { activity (\%) }\end{array}$ \\
\hline 1. & 22 & male & $\begin{array}{l}\text { schizophrenia } \\
\text { disorganized type }\end{array}$ & $\begin{array}{l}\text { haloperidol } \\
\text { levomepromazine } \\
\text { trihexyphenidyl } \\
\text { flunitrazepam }\end{array}$ & $\begin{array}{r}9 \\
200 \\
6 \\
2\end{array}$ & 0.6 & $\begin{array}{l}\text { depressive } \\
\text { mood }\end{array}$ & $71 \rightarrow 49$ \\
\hline 2. & 35 & female & $\begin{array}{l}\text { schizophrenia } \\
\text { paranoid type }\end{array}$ & $\begin{array}{l}\text { bromperidol } \\
\text { chlorpromazine } \\
\text { levomepromazine } \\
\text { biperiden }\end{array}$ & $\begin{array}{r}15 \\
300 \\
100 \\
3\end{array}$ & $0.7-1.1$ & $\begin{array}{l}\text { aggressiveness } \\
\text { autism }\end{array}$ & $43 \rightarrow 78$ \\
\hline 3. & 28 & female & $\begin{array}{l}\text { schizophrenia } \\
\text { paranoid type }\end{array}$ & $\begin{array}{l}\text { haloperidol } \\
\text { levomepromazine } \\
\text { biperiden } \\
\text { flunitrazepam }\end{array}$ & $\begin{array}{r}9 \\
50 \\
2 \\
2\end{array}$ & $0.7-1.1$ & $\begin{array}{l}\text { depressive } \\
\text { mood }\end{array}$ & $31 \rightarrow 51$ \\
\hline 4. & 50 & female & $\begin{array}{l}\text { schizophrenia } \\
\text { disorganized type }\end{array}$ & $\begin{array}{l}\text { bromperidol } \\
\text { levomepromazine } \\
\text { flunitrazepam } \\
\text { biperiden } \\
\text { vegetamin B 1T }\end{array}$ & $\begin{array}{r}18 \\
50 \\
2 \\
2\end{array}$ & 0.4 & nothing & $6 \rightarrow 17$ \\
\hline 5. & 22 & female & $\begin{array}{l}\text { schizophrenia } \\
\text { paranoid type }\end{array}$ & $\begin{array}{l}\text { haloperidol } \\
\text { levomepromazine } \\
\text { thioridazine } \\
\text { biperiden } \\
\text { vegetamin A } 1 \mathrm{~T}\end{array}$ & $\begin{array}{l}19.5 \\
25 \\
50 \\
4\end{array}$ & $0.5-0.8$ & $\begin{array}{l}\text { depressive } \\
\text { mood }\end{array}$ & $7 \rightarrow 26$ \\
\hline 6. & 49 & female & $\begin{array}{l}\text { schizoaffective } \\
\text { disorder } \\
\text { depressive type }\end{array}$ & $\begin{array}{l}\text { haloperidol } \\
\text { levomepromazine } \\
\text { biperiden } \\
\text { zopiclone } \\
\text { flunitrazepam }\end{array}$ & $\begin{array}{l}7.5 \\
80 \\
3 \\
7.5 \\
2\end{array}$ & $0.4-0.6$ & $\begin{array}{l}\text { anxiety } \\
\text { auditory } \\
\text { hallucination } \\
\text { delusion of } \\
\text { reference }\end{array}$ & $69 \rightarrow 69$ \\
\hline
\end{tabular}


his admission. On admission, he showed delusion of reference, delusion of possession, cenesthopathy, incoherence and depressive mood. Four weeks after admission, $600 \mathrm{mg}$ per day of lithium carbonate was added to the neuroleptics. Ten days later, his depressive mood began to improve gradually. However, his daily activity had decreased from $71 \%$ to $49 \%$.

\section{Case 2}

Ms. T was a 35-year-old unmarried woman. She had suffered from schizophrenia for fourteen years. She had been on $8 \mathrm{mg}$ per day of bromperidol and $400 \mathrm{mg}$ per day of chlorpromazine. On admission, because she showed auditory hallucination, delusion of possession, aggressiveness and autism, bromperidol was increased to $15 \mathrm{mg}$ per day, chlorpromazine was decreased to $300 \mathrm{mg}$ per day, and $100 \mathrm{mg}$ per day of levomepromazine was added. Four weeks after admission, $400 \mathrm{mg}$ per day of lithium was added to the neuroleptics, and 2 weeks later, lithium carbonate was increased to $600 \mathrm{mg}$ per day. One week after this increment, her aggressiveness and autism were improved significantly. In addition, her daily activity had increased from $43 \%$ to $78 \%$.

\section{Case 3}

Ms. $M$ was a 28-year-old unmarried woman. She had suffered from schizophrenia for nine years. She had been on $3 \mathrm{mg}$ per day of haloperidol and $25 \mathrm{mg}$ per day of levomepromazine for several years. On admission, she showed auditory hallucination, autism and depressive mood. After admission, haloperidol was increased to $9 \mathrm{mg}$ per day, and levomepromazine was increased to $50 \mathrm{mg}$ per day. Eight weeks after admission, $600 \mathrm{mg}$ per day of lithium carbonate was added to the neuroleptics. Two weeks later, her depressive mood had improved gradually, and her daily activity had also increased from $31 \%$ to $51 \%$.

\section{Case 4}

Ms. O was a 50-year-old unmarried woman. She had suffered from schizophrenia for twenty-five years. She had been on $6 \mathrm{mg}$ per day of bromperidol and $5 \mathrm{mg}$ per day of levomepromazine for several years. On admission, she showed incoherence, auditory hallucination, delusion of observation and labile mood. Thereafter, bromperidol was increased to 18 $\mathrm{mg}$ per day, levomepromazine to $50 \mathrm{mg}$ per day and 1 tablet of Vegetamin B (including 12.5 $\mathrm{mg}$ of chlorpromazine, $12.5 \mathrm{mg}$ of promethazine and $30 \mathrm{mg}$ of phenobarbital) was added. Eight weeks after admission, $400 \mathrm{mg}$ per day of lithium carbonate was added to the neuroleptics. Around 1 month after lithium addition, there was no significant improvement in her condition, however, her daily activity had increased from $6 \%$ to $17 \%$.

\section{Case 5}

Ms. F was a 22-year-old unmarried woman. She had suffered from schizophrenia for eight years. She had been on $19.5 \mathrm{mg}$ per day of haloperidol, $15 \mathrm{mg}$ per day of levomepromazine, 
$110 \mathrm{mg}$ per day pf thioridazine and 1 tablet of Vegetamin A (including $25 \mathrm{mg}$ of chlorpromazine, $12.5 \mathrm{mg}$ of promethazine and $40 \mathrm{mg}$ of phenobarbital) for several years. On admission to our hospital, she showed auditory hallucination, passivity experience, abulia and a depressive mood. After admission, thioridazine was decreased to $50 \mathrm{mg}$ per day, and levomepromazine was increased to $25 \mathrm{mg}$ per day. Four weeks after admission, $600 \mathrm{mg}$ per day of lithium was added to the neuroleptics. Seven days later, her depressive mood began to improve gradually. In addition, her daily activity had increased from $7 \%$ to $26 \%$.

Case 6

Mrs. M was a 49-year-old married woman. She had suffered from schizoaffective disorder for three years. She had been on $150 \mathrm{mg}$ per day of sulpiride, $40 \mathrm{mg}$ per day of levomepromazine and $30 \mathrm{mg}$ per day of mianserin for several months. On admission, she showed anxiety, auditory hallucination, delusion of reference and depressive mood. After admission, sulpiride and mianserin were discontinued, and levomepromazine was increased to $80 \mathrm{mg}$ per day. Three mg per day of haloperidol was added to the other psychotropics, and thereafter it was increased to $7.5 \mathrm{mg}$ per day. Eight weeks after admission, $600 \mathrm{mg}$ per day of lithium carbonate was added to the neuroleptics. Seven days later, anxiety, auditory hallucination and delusion of reference began to improve gradually. However, her daily activity remained unchanged ( $69 \%$ to $69 \%$ ).

In total, as shown in Table 1 , daily activity was improved in 4 cases, unchanged in 1 , and worsened in 1 . On the other hand, depressive mood was improved in 3 patients, aggressiveness and autism were improved in 1 patient, and anxiety, auditory hallucinations and delusion of reference were improved in 1 patient. The other 1 patient remained unchanged. Three of 6 patients (cases 1,4 and 6) showed inconsistent responses with regard to psychiatric symptoms and daily activity. Also, Table 1 shows serum lithium levels measured 1 to 3 weeks after the starting of lithium.

\section{Discussion}

From our results, lithium addition was seen to be effective both for improving psychiatric symptoms and for enhancing daily activity, although this was an open study with a small number of subjects. Moreover, the method and duration of assessment of daily activity was limited. Interestingly, however, there was considerable inconsistency of lithium responses with respect to psychiatric symptoms and daily activity.

These findings suggest that daily activity as measured by the present method is not directly associated with psychiatric symptoms, and that the effects of lithium should also be assessed from the viewpoint of daily activity. 


\section{References}

1. Terao T, Oga T, Nozaki S, Ohta A, Ohtsubo Y, Yamamoto S, Zamami M \& Okada M (1995): Lithium addition to neuroleptic treatment in chronic schizophrenia: a randomized, double-blind, placebocontrolled, cross-over study. Acta Psychiatr Scand 92: 220-224

2. Martin JC, Palenciano G \& Perez R (2000): The effectiveness of combining lithium with olanzapine in the treatment of resistant schizophrenia. J Clin Psychiatry 61: 948

3. Schulz SC, Thompson PA, Jacobs M, Ninan RT, Robinson D, Weiden PJ, Yadalam K, Glick ID \& Odbert CL (1999): Lithium augmentation fails to reduce symptoms in poorly responsive schizophrenic outpatients. J Clin Psychiatry 60: 366-372

4. Geddes J, Freemantle N, Harrison P \& Bebbington P (2000): Atypical antipsychotics in the treatment of schizophrenia: systematic overview and meta-regression analysis. British Medical Journal 321: $1371-1376$

統合失調症（精神分裂病）患者における日常の活動量と精神症状に対するリチウム の効果

征矢 敦至, 寺尾岳, 中村 純

産業医科大学医学部 精神医学教室

要 旨： 6名の統合失調症（精神分裂病）患者にリチウムを投与したところ，ほとんどの患 者で何らかの改善が得られた。しかしながら，3名の患者においては日常生活での 活動量増加と精神症状の改善の間に関連を認めなかった。このことは,リチウムが 精神症状の改善とは無関係に活動量を增している可能性を示唆するものである．精 神症状の改善のみならず, このような活動量も評価すべきであろう.

J UOEH（産業医大誌）24(4): 391-395（2002） 